\title{
Methyl methylthiomethyl sulfoxide
}

土橋源一, 小倉克之

(相模中央化学研究所)

\author{
$\mathrm{MeSCH}_{2} \mathrm{SMe} \underset{\mathrm{AcOH}}{\stackrel{\mathrm{H}_{2} \mathrm{O}_{2}}{\longrightarrow}} \mathrm{MeSOCH}_{2} \mathrm{SMe}$ \\ $108.2 \quad 124.2$
}

\section{I. 製 法}

bis(methylthio)methane ${ }^{1)} 25.09 \mathrm{~g}$ を水酢酸 $50 \mathrm{ml}$ によかし（注意 1 )，磁気かきまぜ機で氷泠下かきまぜながら $30 \%$ 過酸化水素水 $26.5 \mathrm{~m} l$ を滴下する（注意 2 ）。滴下後 30 分（注意 3 ）室温でかきまぜたのち塩化メチレン $300 \mathrm{~m} l$ を加え無水炭酸カリウム $60 \mathrm{~g}$ で中和する（注意 4 ）。固形物を口過により除き， 口液を無水硫酸ナトリウムで乾燥す る。溶媒を減圧下で除去したのち残留物を 減圧蒸留すると $92 \sim 93^{\circ} \mathrm{C} / 2.5 \mathrm{mmHg}$ の沸点を有する methyl methylthiomethyl sulfoxide $22.41 \mathrm{~g}$ が無色液体として得られる。

\section{II. 注 意 事 項}

（1）反応容器は $500 \mathrm{~m} l$ あるいは $1 l$ のビーカーまたはコニカルビーカーを使用する。

(2) 滴下時間は約 15 分でよいが，それ以上長くなることはさしつかえない。

（３）生成物は同条件下で安定なためさらに長時間かきまぜてもよい。

(4) 二酸化炭素が発生するので数回に分け注意しながら加える。

\section{III. 性質}

bp 92 93ㄷ $/ 2.5 \mathrm{mmHg}$ 。無色液体。水，アルコール，塩化メチレン，クロロホルム，ベンゼンおよび四塩化炭素に 可溶。n-ヘキサンに難溶。

\section{IV. 本法の利点}

標題化合物は chloromethyl methyl sulfoxide ${ }^{2)}$ の methyl mercaptide による求核置換反応で得ることができるが3), この場合 chloromethyl methyl sulfoxide が比較的不安定なため大量合成には不適である。本方法は大量に合成できる という点ですぐれている。ここに得られた methyl methylthiomethyl sulfoxide は〔1】式に示すアルデヒドの合成およ ぶ〔2】式のフェニル酢酸誘導体の合成など4 ${ }^{4 *}$ に利用することができる。

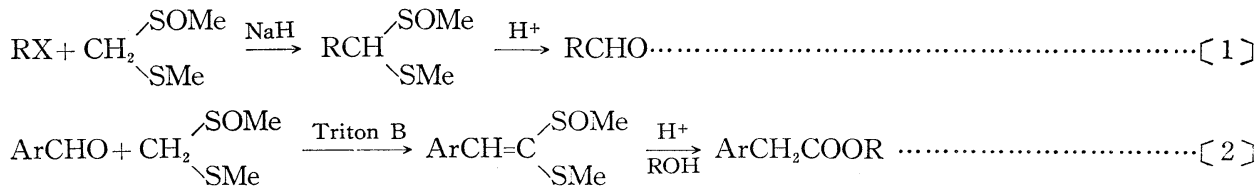

なお他の $\alpha$ 位にスルフィド結合を有するスルホキシド化合物については文献, ${ }^{3,7}$ を参照されたい。

\section{引用文献}

1) H. Böhme, R. Marx, Chem. Ber. 74 B 1667 (1941)

2) G. Tsuchihashi, K. Ogura, Bull. Chem. Soc. Japan 441726 (1971)

3) K. Ogura, G. Tsuchihashi, Chem. Commun. 19701689

4) K. Ogura, G. Tsuchihashi, Tetrahedron Lett. 19713151

5) K. Ogura, G. Tsuchihashi, ibid. 19721383

6) K. Ogura, G. Tsuchihashi, ibid. 19722681

7) K. Ogura, G. Tsuchihashi, Bull. Chem. Soc. Japan 452203 (1972) 